\title{
Robert Sałek
}

Politechnika Częstochowska

e-mail: robert.salek@wz.pcz.pl

\section{ROLA TECHNOLOGII INFORMACYJNYCH JAKO NARZĘDZI INTEGRACJI PROCESÓW TRANSPORTOWYCH W LOGISTYCZNYM ŁAŃCUCHU DOSTAW}

THE ROLE OF INFORMATION TECHNOLOGIES AS TOOLS FOR THE INTEGRATION OF TRANSPORT PROCESSES IN THE LOGISTIC SUPPLY CHAIN

DOI: 10.15611/ie.2017.2.08

JEL Classification: L91, M15, R40

Streszczenie: Ciągłe doskonalenie technologii informacyjnych odzwierciedla kierunki rozwoju współczesnej gospodarki. Otoczenie takie stwarza przedsiębiorstwom wielkie możliwości podążania za globalnym nurtem i dostosowywania swoich działań do wymagań klientów. Znaczącą rolę w procesach gospodarczych i w samych łańcuchach dostaw odgrywają systemy informacyjne, istotnie ułatwiające pozyskiwanie i przetwarzanie informacji na potrzeby zwiększania efektywności przedsiębiorstw. Zjawisko integracji odzwierciedla spójność danej struktury, która dąży do stworzenia sprawnie funkcjonującej całości. Autor w artykule podejmuje problematykę zintegrowanego łańcucha dostaw oraz procesów transportowych jako najważniejszego elementu sprzęgającego wszystkie ogniwa. Dokonuje także identyfikacji poszczególnych systemów informacyjnych w celu określenia ich funkcjonalności w procesach transportowych.

Słowa kluczowe: SCM, IT, transport, zarządzanie.

Summary: The importance and continuous improvement of information technologies reflect the directions of modern economy development. Such an environment gives businesses great opportunities to follow the global trend and adapt their activities to the needs of their customers. A significant role in the economic processes as well as in the supply chains themselves is played by information systems, which significantly facilitate the acquisition and processing of information for the purpose of increasing the efficiency of enterprises. The integration phenomenon reflects the coherence of a structure that seeks to create a wellfunctioning whole. The author in this article addresses the issues of the integrated supply chain and transport processes as the most important linking element for all cells. He also identifies individual information systems to determine their functionality in transport processes.

Keywords: SCM, IT, transport, management. 


\section{Wstęp}

Dążenie do zwiększania efektywności procesów logistycznych przez informatyzację jest jednym $z$ głównych kierunków rozwoju przedsiębiorstw funkcjonujących w zintegrowanych łańcuchach dostaw. Poszukiwanie nowoczesnych rozwiązań wspomagających te procesy wymuszone jest $\mathrm{w}$ dużej mierze wzrostem znaczenia konkurencyjności w sferze rynkowej, jak również skracaniem cyklu życia produktów i zmieniającymi się oczekiwaniami klientów. W związku z tym przedsiębiorstwa transportowe, odpowiedzialne za przepływy dóbr w łańcuchu dostaw, muszą elastycznie reagować na te zmiany, dostosowując swoją działalność tak, by zwiększać efektywność i optymalizować procesy transportowe. Wiąże się to z określonymi inwestycjami w informatyczne systemy logistyczne, które znacznie zwiększają możliwości przedsiębiorstw w ich działalności rynkowej. Informatyzacja procesów logistycznych, a szczególnie przepływów materiałowych, stanowi innowacyjne podejście w rozwoju koncepcji zarządzania łańcuchem dostaw. Odnosi się to także do systemów i podsystemów transportowych wchodzących w jego skład. Możliwości, jakie daje zastosowanie odpowiednich systemów informacyjnych w zarządzaniu, stanowią podstawę do kreowania inteligentnych i integralnych procesów w całym łańcuchu [Serafin 2014].

Wpływ otoczenia oraz postępujące procesy globalizacyjne w dziedzinie transportu i komunikacji to istotny element wywierający wpływ na ewolucję łańcuchów logistycznych, jak również na wzrost dostępności narzędzi i technik skutecznego zarządzania procesami w ich poszczególnych ogniwach. Łańcuchy dostaw w swojej typowej formie obejmują przepływy materiałowe od producentów do magazynów pośredniczących, a w dalszej kolejności do punktów sprzedaży klientom końcowym. W ujęciu szerszym należy je rozpatrywać jako logistyczne układy sieciowe, które tworzone są przez relacje zachodzące między ogniwami w pojedynczym łańcuchu, ale również relacje wykraczające poza jego obszar, skierowane na powiązania z ogniwami innego [Wiśniewska-Sałek 2016]. Najczęściej powiązania te tworzą się u dostawców, w centrach logistycznych i dystrybucyjnych oraz wszędzie tam, gdzie dane ogniwo kooperuje w ramach swojej działalności. Podczas analizy łańcuchów logistycznych pod względem zarządzania i wykorzystania systemów informacyjnych należy wziąć pod uwagę to, że redukcja kosztów oraz wzrost poziomu świadczonych usług stanowią cele nadrzędne determinujące istotność wszystkich stosownych rozwiązań [Waściński 2014]. Celem głównym niniejszego artykułu jest analiza literaturowa z zakresu integracji procesów transportowych w łańcuchach logistycznych oraz podkreślenie istotności zastosowania technologii informacyjnych w tych procesach. Empiryczny aspekt pracy bazuje ściśle na analizie teoretycznej, w której można wyróżnić następujące metody: definiowanie, porównanie, analizę, wnioskowanie i studium przypadku. Zastosowane metody w pierwszej kolejności pozwoliły scharakteryzować zagadnienie zintegrowanych łańcuchów dostaw i podkreślić istotność integracji procesów transportowych. Następnie dokonano analizy i charaktery- 
styki systemów informacyjnych wykorzystywanych w logistyce, a potem przeprowadzono analizę przypadku zastosowania systemów telematycznych jako narzędzia integracji procesów w łańcuchu dostaw.

\section{Koncepcja zintegrowanego lańcucha dostaw - studia literaturowe}

Pojęcie zarządzania łańcuchem dostaw (ZŁD) pojawiło się po raz pierwszy w roku 1982. Odnosiło się wtedy do możliwości redukowania zapasów przedsiębiorstwa oraz firm współpracujących, powiązanych relacjami biznesowymi. R. Oliver i M. Webber, uważani za twórców tego terminu, w swojej pracy [Oliver, Webber 1982] określili rolę naczelnego kierownictwa jako organu zarządzającego łańcuchem dostaw w kwestii identyfikowania konfliktowych celów wynikających z działalności różnych obszarów przedsiębiorstwa. Konflikty te przyczyniać się miały do zaburzania przepływów informacji, produktów i środków finansowych.

Pojęcie ZŁD usystematyzowane zostało po raz pierwszy przez Ch. Bechtela i J. Jayantha [Bechtel, Jayanth 1997]. Dokonali oni strukturyzacji pojęcia, odnosząc się do czterech koncepcji (szkół) myślowych [Waściński 2014], takich jak:

- szkoła wiadomości funkcjonalnej łańcucha: koncentruje się ona na przepływach produktów pomiędzy podmiotami (ogniwami), podkreślając ich znaczenie dla prawidłowości przepływów;

- szkoła zarządzania punktami styku - wzajemnych powiązań (podejście logistyczne): podkreśla istotność powiązań między ogniwami, jak również determinuje doskonalenie metod zarządzania punktami styku [Turner 1993];

- szkoła informacyjna: traktuje przepływy materiałowe i informacji na równie istotnym poziomie, jeżeli po przepływie materiałowym informacja nie będzie generowana w odpowiednim czasie, efektem będą zakłócenia w funkcjonowaniu łańcucha [Johansson 1994].

- szkoła integracyjna: prezentuje najszerszy obraz funkcjonowania łańcucha dostaw, gdzie kontrolowanie i zarządzanie procesami zależne jest o wielu czynników i można to robić na wiele sposobów [Lambert, Cooper, Pagha 1998].

Instytucjonalny wymiar łańcucha dostaw został wyraźnie wskazany w pracy [Martha, Subbakrishna 2002], której autorzy określili go jako „zbiór procesów wewnętrznych i zewnętrznych powiązanych z produkcją, zaopatrzeniem oraz dostawą do klientów, wymagający określonych czynności, takich jak: pozyskiwanie surowców, planowanie produkcji oraz dystrybucja, wspomagane ciągłym przepływem informacji”. Takie podejście pozwala sklasyfikować podmioty oraz ich funkcjonalność na różnych etapach łańcucha. Ważną kwestią są także relacje powstające między ogniwami łańcucha. Ich wielokierunkowy układ scharakteryzowany został przez R.R. Lummusa i K.L. Albera [Lummus, Alber 1997; Lummus, Krumwiede, Vokurka 2001], którzy nadali im formę relacji dwukierunkowej między dostawcą a odbiorcą. Koncepcja ta została rozwinięta przez J.J. Coyle'a, E.J. Bardiego 
i C.J. Langleya [Coyle, Bardi, Langley 2010], którzy podkreślają w swojej pracy rolę integracji w zarządzaniu trzema głównymi przepływami: dóbr, informacji oraz transakcji finansowych, jako najważniejszymi elementami wpływającymi na skuteczne zarządzanie łańcuchem dostaw.

Integracja przepływów w logistycznym łańcuchu dostaw stanowi jeden z najważniejszych obszarów oddziałujących na jego efektywność. Stanowi ona także szeroko podejmowaną tematykę badawczą wśród teoretyków, jest także efektem rozwoju koncepcji łańcucha dostaw w obszarze praktycznym. Integracja definiowana jest jako „proces tworzenia się całości z mniejszych części” [Doroszewski (red.) 1958]. W ujęciu ekonomicznym oznacza ona procesy polegające na scalaniu przedsiębiorstw, działów i gałęzi gospodarki, polegające na tworzeniu jednostki podmiotowej łączącej w sobie wiele mniejszych jednostek. Pojmowanie logistyki w kategoriach systemowych pozwala odnieść się do procesu integracji jako głównego nurtu w realizacji procesów logistycznych. Zakres integracji obejmować może zarówno wewnętrzne działy lub funkcje, jak również wyższe szczeble na poziomie całych przedsiębiorstw [Pfohl 1998].

Rozpatrując integrację wewnątrz łańcucha dostaw, należy odnieść się do pozio$\mathrm{mu}$ integracji między przedsiębiorstwami, które nawiązują współpracę $\mathrm{w}$ celu usprawnienia przepływów strumieni logistycznych w ramach organizacji. Jest ona konieczna do funkcjonowania przedsiębiorstw w konkurencyjnym otoczeniu, a jej celami są redukcja kosztów, wzrost efektywności procesów oraz podniesienie produktywności [Hentschel i in. 2015].

Ogólnie rozumiana gospodarka jest złożonym systemem, w którym podmioty powiązane są relacjami ekonomicznymi, prawnymi oraz środowiskowymi. Łańcuchy dostaw, jako jeden z jej wielu elementów, stanowią szczególne odzwierciedlenie tych relacji przez wieloaspektowe zależności charakteryzujące jego postać. Odnosząc się do pojęcia „łańcuch dostaw”, które sformułowano w ostatnich dziesięcioleciach, należy rozważyć jego trafność w odniesieniu do tak wielu różnych definicji. Przyjęta linowość łańcucha nie odzwierciedla w pełni wszystkich zachodzących w nim zależności. Przybiera on raczej kształt sieci, w której sprzężenia występują między ogniwani w obszarach dystrybucji i zaopatrzenia. Duże znaczenie w tworzeniu relacji sieciowych mają także klastry logistyczne [Nowakowska-Grunt, Jelonek, Kościelniak 2014]. Podstawowa funkcjonalność łańcucha bazuje na zasadach logistyki, lecz to nie ona stanowi o jego sile. Wszelkie działania podejmowane w ramach łańcucha dostaw determinowane są przez popyt, a zatem klientów końcowych. M. Christopher [Christopher 2005] wskazuje, że bardziej trafnym określeniem odzwierciedlającym postać łańcuch dostaw byłaby sieć popytu (demand network). W literaturze przedmiotu często znajduje się odniesienia do sieciowości łańcucha dostaw, jednak powszechnie przyjęta forma jest nadal bardzo popularna. 


\section{Znaczenie integracji procesów transportowych w lańcuchu dostaw}

Podkreślając istotność integracji procesów w łańcuchu dostaw, należy szczególnie zwrócić uwagę na funkcję transportu oraz jego wpływ na działalność przedsiębiorstw w łańcuchu. Transport stanowi nierozłączny element strukturalny, ponieważ odpowiedzialny jest za fizyczne przemieszczanie dóbr, które stanowią podmiot funkcjonowania łańcucha dostaw. Procesy transportowe mogą zostać scharakteryzowane jako zbiór następujących po sobie czynności: przemieszczania, administracyjnych, prawnych, finansowych, organizacyjnych oraz magazynowych. Do najistotniejszych zalicza się czynności organizacyjne wykonywane przed przewozem oraz wykonawcze występujące przed przewozem, w jego trakcie oraz po nim [Kacperczyk 2009].

Szczególną rolę w realizacji procesów transportowych odgrywa spedycja, która może się odbywać w ramach spedycji własnej (wykonywanej samodzielnie przez dysponenta ładunku) bądź też zleconej, kiedy wszelkie obowiązki powierza się profesjonalnym przedsiębiorstwom spedycyjnym lub logistycznym. Spedytor jako osoba odpowiedzialna za przebieg danego procesu pełni funkcję pośrednika między podmiotami zlecającymi przewozy a firmami transportowymi wykonującymi ich fizyczną realizację. $Z$ tego względu jego działania są bardzo istotne dla prawidłowego przebiegu procesu, a tym samym bezpośrednio wpływają na relacje zachodzące w łańcuchu dostaw. Prace przygotowawcze i skuteczny przebieg procesów transportowych wymagają szczegółowych opracowań w kwestii uzyskania najlepszego wariantu dla koncepcji zleceniodawcy. W tym celu dużą uwagę przykłada się do: wyboru właściwych podmiotów realizujących przewozy, negocjacji warunków i cen przewozów, terminowego przesyłania zleceń transportu oraz sporządzenia i zabezpieczenia dokumentacji [Stajniak i in. 2008].

Logistyka, w kontekście realizacji wymagań dotyczących ilości, miejsca i czasu, kreuje powiązania oraz kieruje przepływem dóbr, co w ujęciu systemowym pozwala na koordynację wszystkich podmiotów w łańcuchu dostaw. Integracja fizycznych przepływów materiałowych i informacyjnych stanowi bezwarunkowy warunek do uzyskania wysokiej skuteczności funkcjonowania struktur łańcucha [Jacyna 2007].

Na rysunku 1 schematycznie przedstawiono strukturę zintegrowanego łańcucha dostaw; podkreślono na nim transport jako element scalający poszczególne ogniwa. Integracja zachodzących tam procesów nie byłaby możliwa bez sprawnego przepływu informacji. Wskazuje to na istotną rolę, jaką odgrywają informacyjne systemy logistyczne, które istotnie przyczyniają się do efektywnego przebiegu działań w ramach łańcucha. Dotyczy to przede wszystkim sterowania procesami przemieszczania dóbr oraz identyfikacji problemów decyzyjnych, a także kontroli w ujęciu całego systemu logistycznego i pojedynczych podmiotów w łańcuchu dostaw [Jacyna 2009]. 


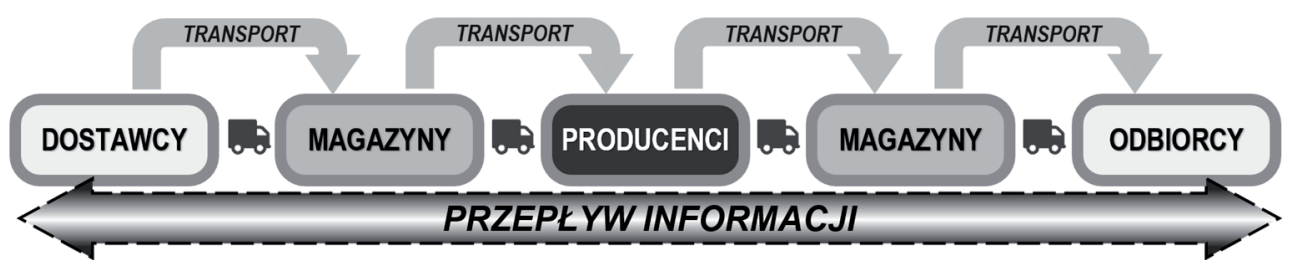

Rys. 1. Zintegrowany łańcuch dostaw w ujęciu systemu logistycznego przedsiębiorstwa Źródło: opracowanie na podstawie [Jacyna 2009, s. 54].

Poziomy układ organizacji zarządzania łańcuchem dostaw, który przyjęty został zgodnie z definicją, zorientowany jest wyraźnie na zarządzanie procesami koncentrującymi się na określonych efektach i potrzebach rynku [Christopher 2000]. Tego typu orientację należy wiązać z logistyką, która stanowić powinna obszar spajający procesy wymuszone przez gospodarkę rynkową.

Sieciowe ujęcie łańcucha dostaw podkreśla charakter poszczególnych ogniw, które determinują jego kształt przez określenie:

- trwałości,

- struktury lańcucha,

- partnerów,

- poziomu zwinności i elastyczności,

- poziomu adaptacji uczestników (ujęcie lidera).

Przez racjonalne powiązanie efektywności i elastyczności w konkretnych obszarach możliwe jest zwiększenie intensywności strumieni przy zmniejszonych kosztach operacyjnych oraz kosztach zapasów [Hugos 2011]. Współczesne łańcuchy dostaw, jako element gospodarki światowej, podlegają procesom globalizacji ze względu na globalny zasięg procesów produkcji i dystrybucji. Zadania logistyczne wykonywane w ramach łańcuchów są uzależnione zatem od zmian zachodzących w jego otoczeniu (globalizacja, regionalizacja, ekologia, e-handel) oraz od czynników wewnętrznych (optymalizacja i synchronizacja działań, elastyczność zdolności adaptacyjnych, szybkość przepływów, opłacalności podejmowanych relacji) usytułowanych w poszczególnych ogniwach [Antonowicz 2016].

Integracja transportu lub szerzej rozumianych systemów transportowych koncentruje się na procesach przewozowych, a w szczególności na skupianiu czynności rozproszonych. Uzyskanie całkowitej integracji ma charakter stopniowy, a zasięg i waga procesów integracyjnych są uzależnione od ciągłej ewolucji systemów ekonomicznych. Istnieje więc ścisła zależność między systemami transportowymi a gospodarczymi, które się przenikają i oddziałują na kształt procesów integracji. Sytuacja ta powoduje, że niezbędne jest dokonywanie integracji na najniższych poziomach systemów transportowych w odniesieniu do czynności związanych z przepływami materiałowymi między punktami nadania i przeznaczenia [Mindur, Stajniak 2009]. 
W praktyce występuje znaczne zróżnicowanie w kształtowaniu się procesów integracyjnych w systemach transportowych. Jest to elektem zróżnicowania w analizach zjawisk zachodzących w procesach integracyjnych, które przybierają postać działań sekwencyjnych [Michałowska (red.) 2007].

Procesom integracji w łańcuchach logistycznych i transporcie podlegają określone obszary [Reichhart, Holweg 2006]:

- przepływy informacyjne,

- działania organizacyjne,

- synchronizacja i podział zasobów,

- planowanie przestrzenne i logistyczne.

Należy podkreślić szczególną rolę transportu samochodowego, który jest najbardziej popularną metodą przemieszczania dóbr w łańcuchu logistycznym. Stanowi on także podstawowy element większości systemów logistycznych, których efektywne funkcjonowanie umożliwia dostosowanie się do wymagań klientów. Wiedza z zakresu transportu samochodowego to kluczowy element w kreowaniu procesów współczesnej gospodarki. Stwierdzenie to odzwierciedla również istotę logistyki, której podstawowym zadaniem jest racjonalizacja strumieni, ściśle uzależniona od sprawnych procesów transportowych. Występowanie zróżnicowania ich roli w odniesieniu do złożoności tych procesów jest istotne na każdym przypadku [Mindur (red.) 2002], szczególnie uwzględniając średni udział kosztów przemieszczania ładunków, które stanowią około 40\% całości kosztów logistycznych [Kovács, Kot 2016]. Efektem tego jest rosnące zainteresowanie systemami informacyjnymi oraz rozwiązaniami organizacyjno-technicznymi, dzięki którym możliwe byłoby usprawnienie czynności i operacji w procesach transportowych, a tym samym skrócenie czasów transportu pomiędzy poszczególnymi podmiotami w całym łańcuchu dostaw [Mindur, Stajniak 2009].

\section{Zastosowanie technologii informacyjnych $w$ transporcie}

Współczesne przedsiębiorstwa transportowe nieustannie poszukują nowych rozwiązań w celu usprawnienia swojej działalności. W ujęciu koncepcji zarządzania łańcuchem dostaw każdy jego uczestnik ma znaczny wpływ na tworzenie wartości dodanej, a konkurencja powinna ustąpić miejsca integracji działań [Cywka 2007]. Zintegrowane łańcuchy dostaw umożliwiają złożone relacje między dostawcami, magazynami, produkcją oraz klientem, jednak elementami spajającymi wszystkie działania są transport i spedycja. Połącznie działalności wszystkich ogniw oraz technologii informacyjnych stwarza nowe możliwości kreowania powiązań przez logistyczne systemy informacyjne (LSI). Zależności te przedstawia rys. 2.

Istotnymi narzędziami wspomagającym procesy integracji niewątpliwie są informatyczne systemy zarządzania przedsiębiorstwem. Ciągły rozwój technologii informacyjnych stwarza ogromne szanse na usprawnienie procesów integracji łańcucha dostaw, jak również otwiera nowe możliwości wobec budowania relacji. 


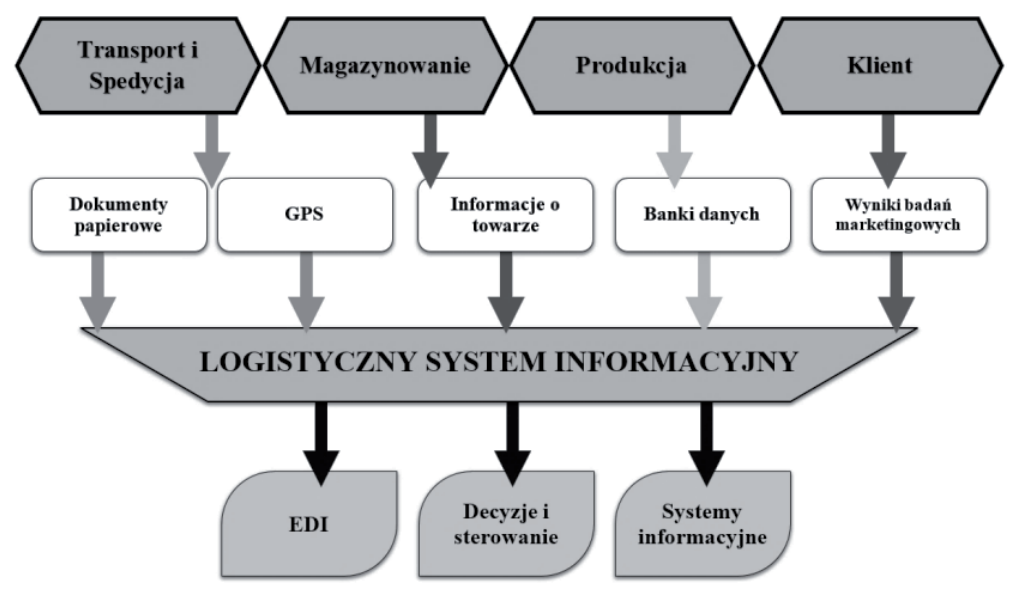

Rys. 2. Integracja operatorów TSL z ogniwami łańcucha dostaw w logistycznym systemie informacyjnym Źródło: opracowanie na podstawie [Gołembska, Szymczak 2004, s. 112].

Współczesne systemy charakteryzują się szerokim zakresem funkcjonalnym oraz otwartością na zmieniające się warunki rynkowe. Stanowi to o ich sile i istotności dla zarządzania współczesnymi łańcuchami, szczególnie ze względu na możliwości wieloaspektowej integracji [Klonowski 2004].

Najważniejszym jej elementem jest wymiana informacji, której sprawny przepływ determinuje wszystkie działania i powiązania w łańcuchach dostaw. Wdrożenie wyspecjalizowanego systemu informatycznego u wszystkich partnerów umożli-

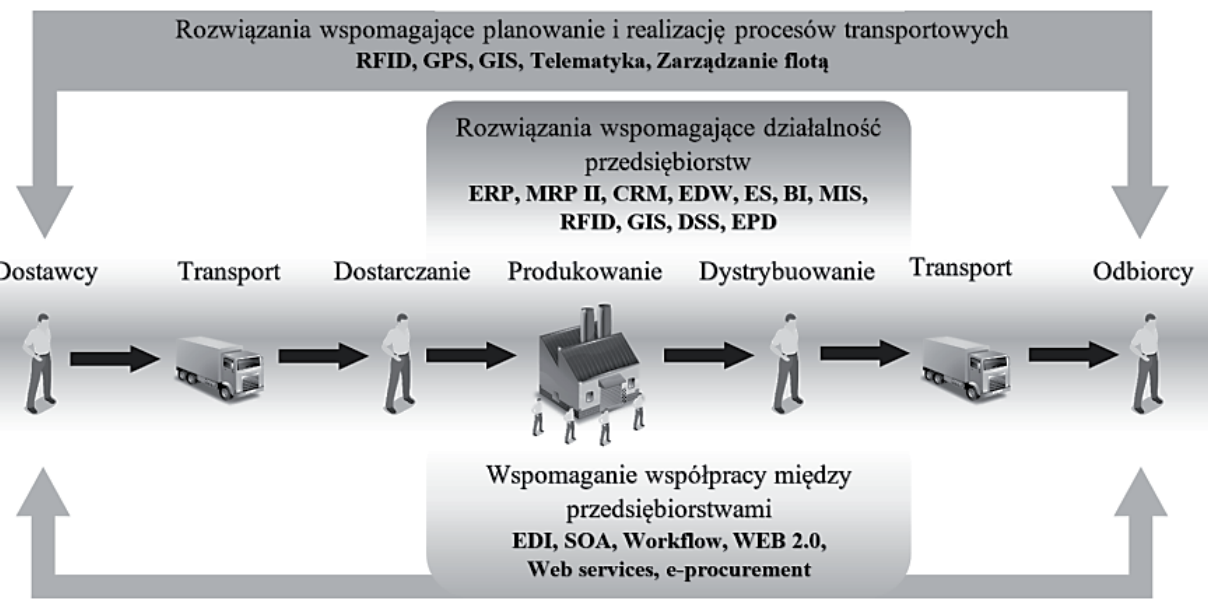

Rys. 3. Wykorzystanie technologii informacyjnych w zintegrowanym łańcuchu dostaw Źródło: opracowanie na podstawie [Hołubowicz, Samp 2008, s. 58]. 
wia kompletne przepływy informacji w zakresie: obrotów towarowych, zapasów, realizacji zleceń, transportu i dostępności środków transportowych. Szeroki zakres informacji, a w szczególności ilość potrzebnych do przetworzenia danych, ukierunkował rozwój obecnie wykorzystywanych rozwiązań operujących w czasie rzeczywistym [Cudziło 2013].

Każdy obszar charakteryzuje się zastosowaniem innej technologii w celu uzyskania lub przetworzenia konkretnych informacji. Na rysunku 3 zobrazowano poszczególne obszary oraz technologie informacyjne wykorzystywane w zintegrowanym łańcuchu dostaw.

W ujęciu zarządzania zintegrowanym łańcuchem dostaw oraz budowaniu relacji między poszczególnymi ogniwami można wyróżnić trzy podstawowe obszary zastosowania technologii informacyjnych [Długosz 2006]:

- wspomaganie współpracy między podmiotami: EDI, SOA (Service Oriented Architecture), Workflow, WEB 2.0, Web services, e-procurement [Hołubowicz, Samp 2008];

- wspomaganie funkcjonowania przedsiębiorstwa: ERP, MRP II, CRM, EDW (Enterprise Data Warehouse), ES (Expert Systems), BI (Business Intelligence), MIS (Management Information System), RFID, GIS, DSS (Decision Support Systems), EPD (Electronic Data Processing) [Klonowski 2004];

- wspomaganie planowania i realizacji procesów transportowych: RFID, GPS, GIS, telematyka, zarządzanie flotą.

Wyróżnione wcześniej obszary stosowania technologii informacyjnych bardzo często się przenikają. W odniesieniu do procesów transportowych daje to dodatkową możliwość interpretacji wykorzystania informacji w celu usprawnienia przepływów materiałowych.

Rysunek 4 przedstawia etapy procesu transportowego oraz możliwe do zastosowania systemy informacyjne zarządzania.

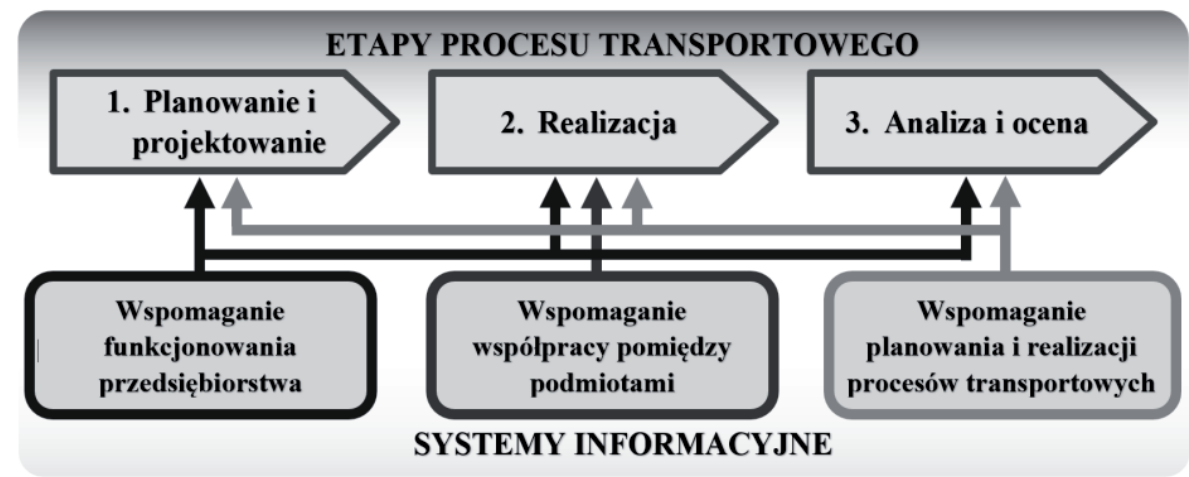

Rys. 4. Zastosowanie systemów informacyjnych w procesie transportowym

Źródło: opracowanie własne na podstawie [Kaup, Chmielewska-Przybysz 2012, s. 854]. 
Wdrażanie nowoczesnych rozwiązań w dziedzinie transportu stanowi duży krok ku integracji procesów w łańcuchach dostaw. Jedną z ważniejszych kwestii szeroko poruszanych $\mathrm{w}$ ostatnich latach są systemy telematyczne. Łączą one w sobie wiele rozwiązań z dziedzin telekomunikacji, informatyki oraz zarządzania. Podstawą funkcjonowania takich systemów jest pozyskiwanie i przetwarzanie informacji $\mathrm{z}$ różnych źródeł $\mathrm{w}$ celu wspomagania procesów decyzyjnych w zarządzaniu flotą pojazdów. Gromadzenie informacji w bazach systemowych możliwe jest dzięki zastosowaniu nowoczesnych i innowacyjnych technologii. Dotyczy to przede wszystkim urządzeń pokładowych instalowanych bezpośrednio w pojazdach (elektroniczne tachografy, czujniki monitorowania parametrów technicznych pojazdów, GPS itd.), jak również urządzeń funkcjonujących jako elementy infrastruktury transportowej (kamery, stacje pogodowe, inteligentne systemy transportu - ITS ${ }^{1}$ ). Przetworzenie pozyskanych informacji odbywa się za pomocą systemów informatycznych umożliwiających szybką ocenę realizacji procesów transportowych pod względem jakości i opłacalności. Informacje te stanowią bardzo często czynniki decydujące o przewadze konkurencyjnej przedsiębiorstw. Intensywny rozwój polskiego sektora TSL w ostatnich latach spowodował również zwiększenie tempa rozwoju systemów telematycznych [Badzińska, Cichorek 2015].

Technologie tworzące systemy telematyczne są dodatkowo wspierane przez metody zarządzania i sterowania sieciami oraz systemami transportowymi. Połączenie to stanowi kolejny etap rozwoju systemów zarządzania flotą pojazdów i określone zostało jako telematyka transportu. Głównym celem zastosowania omówionych rozwiązań jest: zwiększenie bezpieczeństwa, optymalizacja czasów przejazdów oraz zmniejszenie zużycia paliwa i emisji $\mathrm{CO}_{2}$ [Baumgartner, Léonardi, Krusch 2008]. Integracja fizycznych systemów transportowych, technologii telematycznych oraz metod zarządzania, stanowi odpowiedź na ciągle zmieniające się warunki rynkowe, w których przedsiębiorcy jako ogniwa logistycznych łańcuchów dostaw muszą reagować szybko i sprawnie aby sprostać wymaganiom klientów.

\section{Integracja procesów w lańcuchu dostaw poprzez zastosowanie systemów telematycznych - case study}

Podmiotem analizy jest przedsiębiorstwo transportowe PT prowadzące działalność rynkową od dziewiętnastu lat. Przez cały okres funkcjonowania stale rozwijała się w obszarach zarówno zarządzania, jak i samych rozwiązań technicznych. Początkowo realizowano zlecenia krajowe, by następnie rozszerzyć zasięg świadczonych usług do zleceń międzynarodowych. Dążenie do zoptymalizowania procesów trans-

1 „Systemy, które stanowią szeroki zbiór różnorodnych technologii (telekomunikacyjnych, informatycznych, automatycznych i pomiarowych) oraz technik zarządzania stosowanych $\mathrm{w}$ transporcie w celu ochrony życia uczestników ruchu, zwiększenia efektywności systemu transportowego oraz ochrony zasobów środowiska naturalnego" [http://www.itspolska.pl]. 
portowych wymusiło decyzję o wdrożeniu systemu telematycznego. W okresie testowym przeprowadzonym w 2015 r. zaimplementowano trzy różne systemy: T-matic, MAN Telematics oraz EcoFleet SeeMe, z których ostatni wykazywał najlepsze dostosowanie technologiczne do posiadanego taboru i spełniał większość wymagań stawianych przez przedsiębiorstwo. Motywem wdrożenia nowych rozwiązań była przede wszystkim potrzeba kontroli pracy kierowców oraz parametrów eksploatacyjnych taboru w celu obniżenia kosztów usług. Działania podejmowane w tym zakresie pozwalają na wzrost efektywności procesów transportowych oraz optymalne wykorzystanie pojazdów.

Dzięki wdrożeniu systemów telematycznych w przedsiębiorstwie PT wytyczono nowe normy zużycia paliwa. Pozwoliło to na wykluczenie możliwości kradzieży oraz nieekonomicznej jazdy. Przed wdrożeniem systemów średnie spalanie oleju napędowego na $100 \mathrm{~km}$ dla poszczególnych ciągników wynosiło: Renault Magnum - 36 litrów, MAN - 35 litrów. Po wprowadzeniu systemu spalanie w Renault wynosiło 29-31 litrów, natomiast w autach MAN - 28-30 litrów. Dodatkowo kontrola pracy kierowców i parametrów eksploatacyjnych umożliwiła zwiększenie pokonywanego dziennego dystansu o 8-10\%. Dzięki osiągniętym wynikom udało się zwiększyć efektywność procesów transportowych, co przełożyło się na liczbę pokonywanych kilometrów w skali miesiąca (przed wdrożeniem: 9,5-10 tys. km, obecnie: 10,5-12 tys. km). Należy podkreślić, że wyniki te przekładają się bezpośrednio na efektywność procesów w całym łańcuchu dostaw badanego przedsiębiorstwa. Korzyści płynące z zastosowania systemów telematycznych zaobserwować można w odniesieniu do wszystkich ogniw, a w szczególności w odniesieniu do: jakości obsługi klientów, wzrostu konkurencyjności i efektywności ekonomicznej przedsiębiorstwa [Badzińska, Cichorek 2015].

\section{Zakończenie}

Budowanie skutecznych powiązań w logistycznych łańcuchach dostaw stanowi podstawową zasadę do kształtowania rzeczywistości gospodarczej. Dzięki relacjom biznesowym i partnerskim, niezależnie od sfery gospodarki, możliwe jest stworzenie zintegrowanego systemu, który w znacznym stopniu zwiększy swoją funkcjonalność i efektywność rynkową. Koncentrując się na łańcuchach dostaw, należy interpretować je jako rozbudowane sieci wieloaspektowych powiązań w których decydującym elementem jest odpowiednio ukierunkowany przepływ informacji. Zastosowanie systemów informacyjnych i informatycznych w zarządzaniu procesami łańcucha przyczynia się do usprawnienia przepływów informacyjnych, a tym samym to podniesienia intensywności reakcji na impulsy płynące z otoczenia. Podmiotem generującym przepływy informacji i pieniędzy jest transport, czyli zjawisko fizycznego przemieszczania dóbr w celu uzyskania określonych wyników finansowych i zaspokojenia potrzeb klientów. Integracja procesów transportowych w logistycznym łańcuchu dostaw polega na odpowiednim kształtowaniu zależności między informa- 
cją a przemieszczeniem, kiedy informacja może pełnić różne funkcje w zależności od zastosowanego systemu informatycznego. Może ona być ogólna, przepływająca między partnerami w łańcuchu, lub też sterująca, wpływająca na przebieg danego procesu. Istotny w obu przypadkach jest dobór odpowiednich narzędzi i systemów umożliwiających pozyskanie ich przez wszystkie podmioty w łańcuchu dostaw.

\section{Literatura}

Antonowicz M., 2016, Wyzwania logistyczne firm - elastyczne tańcuchy dostaw, Studia Ekonomiczne, Zeszyty Naukowe Uniwersytetu Ekonomicznego w Katowicach, nr 255, s. 217-218.

Badzińska E., Cichorek S., 2015, Systemy telematyczne jako wsparcie zarządzania flota pojazdów w transporcie drogowym - studium przypadku, Zeszyty Naukowe Uniwersytetu Szczecińskiego, nr 875, Problemy Zarządzania, Finansów i Marketingu, nr 41, tom 2, s. 412.

Baumgartner M., Léonardi J., Krusch O., 2008, Improving computerized routing and scheduling and vehicle telematics: A qualitative survey, Transportation Research Part D, 13, s. 377-382.

Bechtel Ch., Jayanth J., 1997, Supply chain management: A strategic perspective, "International Journal of Logistics Management", vol 8, no. 1, s. 15-34.

Christopher M., 2000, Logistyka i zarządzanie łańcuchem dostaw, strategie obniżki kosztów i poprawy poziomu ustug, wydanie II, PCDL.

Christopher, M., 2005, Logistics and Supply Chain Management: Creating Value-Adding Networks, 3rd ed., Harlow:, FT Prentice Hall, New York.

Coyle J.J., Bardi E.J., Langley C.J. Jr., 2010, Zarządzanie logistyczne, Polskie Wydawnictwo Ekonomiczne, Warszawa.

Cudziło M., 2013, Wybrane problemy decyzyjne w zarzadzaniu procesami logistycznymi, Zeszyty Naukowe Politechniki Poznańskiej, Organizacja i Zarządzanie, nr 61, s. 11.

Cywka M., 2007, Narzędzia informatyczne a efektywność zarządzania w logistycznym tańcuchu dostaw, Biuletyn WAT, vol. 56, numer specjalny, s. 263.

Długosz J., 2006, Kryteria oceny nowoczesnych technologii w transporcie, [w:] E. Załoga (red.), Współczesne procesy i zjawiska w transporcie, Uniwersytet Szczeciński, Szczecin, s. 21-26.

Doroszewski W. (red.), Stownik języka polskiego (1958-1969), PWN, Warszawa.

Gołembska E., Szymczak M., 2004, Logistyka międzynarodowa, PWE, Warszawa.

Hadaś Ł., Cyplik P. (red.), 2012, Praktyczne aspekty wykorzystania systemów ERP w wybranych przedsiębiorstwach Wielkopolski, L-Systems Robert Pawlak, wydanie I, Poznań.

Hentschel B., Cyplik P., Hadaś Ł., Domański R., Adamczak M., Kupczyk M., Pruska Ż., 2015, Wieloaspektowe uwarunkowania integracji lańcucha dostaw typu forward i backward. Modelowanie i ocena stopnia integracji, Wyższa Szkoła Logistyki, Poznań.

Hołubowicz W., Samp K., 2008, Informacja i informatyka w logistyce, Polski Kongres Logistyczny Logistics 2008 , „Nowe wyzwania - nowe rozwiązania”, Poznań, 7-9 maja 2008.

Hugos M., 2011, Zarządzanie łańcuchem dostaw, Helion, Gliwice.

http://www.itspolska.pl.

Jacyna I., 2009, Rola transportu w realizacji procesów logistycznych przedsiębiorstwa, Prace Naukowe Transport, z. 69, OWPW, Warszawa.

Jacyna M., 2007, Wybrane aspekty zastosowania techniki komputerowej w analizie realizacji procesów logistycznych, Prace naukowe Transport, z. 63, OWPW, Warszawa.

Johansson L., 1994, How can a TQEM approach add value to your supply chain?, Total Quality Environmental Management, vol. 3, no. 4, s. 525.

Kacperczyk R., 2009, Transport i spedycja. Część 2. Spedycja, Difin, Warszawa. 
Kaup M., Chmielewska-Przybysz M., 2012, Rola i znaczenie technologii informatycznych w organizacji i zarzadzaniu transportem, Logistyka 6, s. 854.

Klonowski Z.J., 2004, Systemy informatyczne zarządzania przedsiębiorstwem. Modele rozwoju i właściwości funkcjonalne, OWPW, Wrocław.

Kovács G.Y., Kot S., 2016, New logistics and production trends as the effect of global economy changes, Polish Journal of Management Studies, vol. 14, no. 2, s. 118.

Lambert D., Cooper M., Pagha J., 1998, Supply chain management: Implementation issues and resarge opportunities, International Journal of Logistics Management, vol. 0, no. 2, s. 1.

Lummus R.R., Alber K.L., 1997, Supply Chain Management: Balancing the Supply Chain with Customer Demand, Falls Church, VA.

Lummus R.R., Krumwiede D.W., Vokurka R.J., 2001, The relationship of logistics to supply chain management, developing a common industry definition, Industrial Management and Data Systems, vol. 1001 , no. 8, s. 426-431.

Martha J., Subbakrishna S., 2002, Targeting a just-in-case supply chain for the inevitable next disaster, Supply Chain Management Review, vol. 6, no. 5, s. 18-23.

Michałowska M. (red.), 2007, Procesy integracyjne wybranych systemów transportowych, Wydawnictwo Akademii Ekonomicznej, Katowice.

Mindur L. (red.), 2002, Wspótczesne technologie transportowe, Wydawnictwo Politechniki Radomskiej, Warszawa.

Mindur M., Stajniak M., 2009, Integracyjna rola transportu $w$ systemach logistycznych przedsiębiorstw, Zeszyty Naukowe, Logistyka i Transport, vol. 8, no. 1, s. 123-129.

Nowakowska-Grunt J., Jelonek D., Kościelniak H., 2014, Logistics' clusters as a part of regional policy in Poland, 3rd International Conference on Advanced Logistics and Transport (ICALT'2014), Yassmine Hammamet, Tunezja.

Oliver R., Webber M., 1982, Supply Chain Management: Logistics Catches Up with Strategy, Outlook.

Pfohl H.Ch., 1998, Zarządzanie logistyką. Funkcje i instrumenty, Biblioteka Logistyka, Poznań.

Reichhart A., Holweg M., 2006, Creating the Customer-Responsive Supply Chain, Judge Business School, Cambridge.

Serafin E., 2014, Systemy informatyczne w logistyce, Logistyka, nr 3, s. 5655-5660.

Stajniak M., Hajdul M., Foltyński M., Krupa A., 2008, Transport i spedycja, Instytut Logistyki i Magazynowania, Poznań.

Turner J., 1993, Integrated supply chain management: What's wrong with picture?, Industrial Engineering", vol. 25 , no. 12 , s. 52.

Waściński T., 2014, Procesy logistyczne w zarządzaniu łańcuchem dostaw, Zeszyty Naukowe Uniwersytetu Przyrodniczo-Humanistycznego w Siedlcach, nr 103, Administracja i Zarządzanie.

Wiśniewska-Sałek A., 2016, Building the economy of the country and management of the local economy from the perspective of industrial specialization, World Scientific News, vol. 57, s. 342-360. 